\title{
Using form-focused tasks to integrate language across the immersion curriculum
}

\author{
Roy Lyster \\ Faculty of Education, McGill University, 3700 McTavish Street, Montreal, Quebec H3A 1Y2, Canada
}

\section{A R T I C L E I N F O}

\section{Article history:}

Received 7 July 2014

Received in revised form 28 August 2014

Accepted 15 September 2014

Available online 12 October 2014

\section{Keywords:}

Immersion

Integrated learning

Form-focused tasks

Counterbalanced instruction

Language across the curriculum

\begin{abstract}
A B S T R A C T
This article reports on two form-focused quasi-experimental intervention studies conducted in French immersion classrooms in the Montreal area, each of which involved a different task-based approach that crossed borders either between content areas or between languages.

The first study integrated a focus on grammatical gender across 5th-grade students' (10 -11 years old) language arts, social studies, and science classes. Students engaged in formfocused tasks that were related to these different content areas and that also drew their attention to noun endings that reliably predict grammatical gender. The content focus then provided contexts for practice in associating gender attribution with noun endings.

The second study integrated a linguistic focus on derivational morphology that crossed borders between the English and French classes of 2nd-grade students (7-8 years old). Their teachers co-designed and implemented biliteracy tasks associated with the French and English editions of illustrated storybooks that they read aloud in their respective French and English classes. The storybooks and related tasks were employed to highlight cross-lingual connections between languages and to enhance students' awareness of derivational morphology.

In addition to reporting the positive outcomes of both interventions, the article addresses some of the challenges that arise when tasks are extended across languages and content areas.
\end{abstract}

(c) 2014 Elsevier Ltd. All rights reserved.

\section{Introduction}

The purpose of this article is to illustrate the use of form-focused tasks as a means to integrate a language focus across the immersion curriculum in two different ways: first, by crossing borders between content areas and, second, by crossing borders between target languages. The article begins with the rationale for integrating a language focus across the immersion curriculum.

The idea that second language (L2) acquisition is primarily input driven and thus best proceeds implicitly without the need for explicit instruction predominated in the 1980s (e.g., Krashen, 1985). Because of its emphasis on comprehensible input to convey subject matter, Krashen (1984) claimed that immersion may be "the most successful program ever recorded in the professional language-teaching literature" (p.64). At the same time, however, Canadian studies of L2 learners in content-based programs such as French immersion (e.g., Swain, 1985) and also intensive ESL programs based on communicative language

E-mail address: roy.lyster@mcgill.ca. 
teaching (Lightbown \& Spada, 1990) began revealing that students in these programs exhibited high levels of communicative ability but lower-than-expected levels of linguistic accuracy. This led scholars in the early 1990s (e.g., Long, 1991; Stern, 1990) to argue for the integration of form-oriented and meaning-oriented approaches to maximize the effects of L2 teaching.

In this regard, Spada (1997) provided promising evidence for the effectiveness of form-focused instruction, which she defined as "any pedagogical effort which is used to draw the learners' attention to form either implicitly or explicitly ... within meaning-based approaches to L2 instruction [and] in which a focus on language is provided in either spontaneous or predetermined ways" (p. 73). A flexible instructional approach that ranges from an implicit to a more explicit focus on language is important for two reasons. On the one hand, classroom learners can learn many L2 forms and functions implicitly if they are exposed to sufficient quantities of rich input. On the other hand, an exclusively incidental focus on the target language in classroom settings has proven too brief and too perfunctory to convey sufficient information about certain grammatical subsystems (Lyster, 2007).

Form-focused instruction has been operationalized as either proactive or reactive (Doughty \& Williams, 1998; Rebuffot \& Lyster, 1996). Proactive form-focused instruction involves pre-planned instruction designed to enable students to notice and to use target language features that are otherwise difficult to learn through exposure to classroom input. Reactive formfocused instruction occurs in response to students' language production during teacher-student interaction and includes corrective feedback as well as other attempts to draw learners' attention to the target language.

In classroom research specifically in immersion settings, proactive form-focused research has often been operationalized as a recursive sequence of noticing, awareness, and practice activities (Lyster, 2007). In the noticing phase, students engage in activities designed to draw their attention to problematic target features contrived to appear more salient and/or frequent in oral and written input. In the awareness phase, students participate in activities that require them to do more than merely notice enhanced forms in the input and instead to engage in some degree of reflection. Awareness activities include inductive rule-discovery tasks, opportunities to compare and contrast language patterns, and different types of metalinguistic information. In the practice phase, students engage in tasks that create obligatory contexts for meaningful use of problematic target forms that are otherwise misused or avoided.

A set of intervention studies conducted in French immersion classrooms ranging from 1st to 8th grade demonstrated the variable effects of form-focused instruction on a range of challenging target features in French: grammatical gender (Harley, 1998; Lyster, 2004), second-person pronouns (Lyster, 1994), conditional verb forms (Day \& Shapson, 2001), functional distinctions between perfect and imperfect past tenses (Harley, 1989), verbs of motion (Wright, 1996), and derivational morphology (Lyster, Quiroga, \& Ballinger, 2013). The instructional treatments in these intervention studies generally proved effective at improving target language accuracy, but especially so in cases where the activities differed from other activities more typical of content-based instruction. That is, effective interventions required an intentional and systematic focus on language that countered the more typical expectation that meaning-oriented instruction should only draw learners' attention to language incidentally. Thus, guided practice activities with role plays and language games, in tandem with noticing and awareness tasks, led to more robust changes than more open-ended communicative tasks involving negotiation for meaning.

This observation led Lyster and Mori (2006) to propose the counterbalance hypothesis, which predicts that interlanguage restructuring is triggered by instructional interventions that orient learners in the direction opposite to that which their target language learning environment has accustomed them. Counterbalance, defined as "a power or influence that balances the effect of a contrary one" (Brown, 1993), is used in this sense to emphasize the complementarity of both form-oriented and meaning-oriented approaches to L2 teaching, as research has long suggested. Counterbalanced instruction is predicated on Skehan's (1998) argument for pushing learners who are either form-oriented or meaning-oriented in the opposite direction in order to strike a balance between the two orientations. That is, learners in language-focused classrooms are expected to benefit from a greater emphasis on substantive content that enriches classroom discourse and enhances their communicative abilities, and learners in content-based and communicatively oriented classrooms are expected to benefit from a greater focus on language that pushes them forward in their L2 development. Learners specifically in immersion and content-based classrooms are expected to benefit from instruction that requires them to vary their attentional focus between the content to which they usually attend in classroom discourse and target language features that are not otherwise attended to. The effort extended to shift attention between form and meaning in this way, and to maintain a recursive interplay, is expected to strengthen connections in memory and, thus, to facilitate access to newly analysed or reanalysed representations.

Many ways have been proposed to draw learners' attention to language during the meaning-oriented discourse that prevails in immersion classrooms (e.g., focus on form, collaborative dialogue, corrective feedback, negotiation of form). The present article aims to illustrate two different approaches, both of which entail the implementation of form-focused tasks across the curriculum. The first approach involves tasks that cross borders between content areas and is illustrated by a classroom intervention study employing form-focused instruction to target grammatical gender in French (Lyster, 2004). The second approach involves tasks that cross borders between language classes and is illustrated by a classroom intervention study implementing counterbalanced instruction to target derivational morphology in both French and English (Lyster et al., 2013).

\section{Integrating form-focused tasks across content areas}

This first approach integrated a focus on grammatical gender across 5th-grade students' (10-11 years old) language arts, social studies, and science classes, as illustrated in Fig. 1 and described in detail in Lyster (2004). The aim of the instructional design was to integrate a specific focus on language across the curriculum. Language across the curriculum is a curricular 


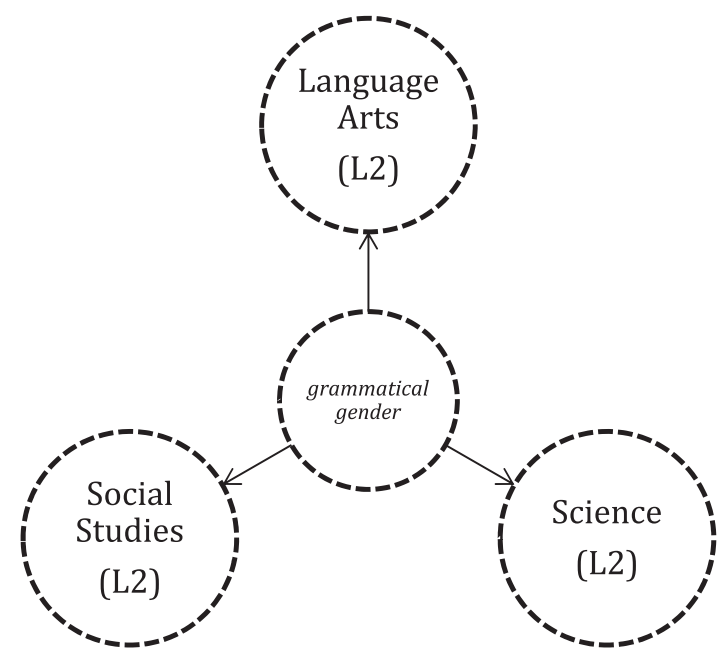

Fig. 1. Integrating form-focused tasks across content areas.

approach brought to the fore in A language for life (Bullock, 1975; also known as the Bullock Report) that emphasized language development across all content areas of the curriculum. Specifically, it makes a student's language education at school the responsibility of all teachers, regardless of their particular subject area. Because of their aim to foster L2 development across various content areas, immersion programs lend themselves well to such an approach. The integration of language and content, however, continues to prove challenging for immersion teachers (Cammarata \& Tedick, 2012), but is still considered at the heart of effective immersion pedagogy. As Lightbown (2014) suggested, separating language and content "may deprive students of opportunities to focus on specific features of language at the very moment when their motivation to learn them may be at its highest" (p. 30). The study reported here involved 5th-grade immersion teachers who each taught language arts, social studies, and science, a situation that facilitated the integration of a language focus across these content areas.

\subsection{Why focus on grammatical gender?}

A quintessential example of differences between L1 and L2 acquisition is evident in the seemingly effortless acquisition of grammatical gender by native speakers of French on the one hand, and the notoriously difficult and often incomplete acquisition of this same grammatical subsystem by many L2 learners of French on the other. Karmiloff-Smith (1979) reported that, by the age of 3-4 years old, French-speaking children develop "a very powerful, implicit system" (p. 167) for accurate gender attribution. In contrast, Tucker, Lambert, and Rigault (1977) remarked that, "the necessity to master grammatical gender may be the single most frustrating and difficult part of the study of French as a second language" (p. 11). Grammatical gender markers are not salient in classroom discourse (e.g., Poirier \& Lyster, 2014) and do not convey, in the case of inanimate nouns, any semantic distinctions. Moreover, grammatical gender does not exist in English.

Influenced by the many French grammarians who claim that grammatical gender is arbitrary and unsystematic in the case of inanimate nouns, L2 teachers encourage students to learn gender attribution on an item-by-item basis, and often do so through incidental reminders. Contrary to assertions put forth in many French grammar books, however, a helpful mnemonic for L2 learners of French is that gender attribution is rule-driven and based on word-internal structural properties, as revealed by Tucker et al.'s (1977) observation that "distinctive characteristics of a noun's ending and its grammatical gender are systematically related" (p. 64). In an analysis of nearly 10,000 nouns in the dictionary Le Robert Junior Illustré, I corroborated Tucker et al.'s finding by operationalizing noun endings as orthographic representations of rhymes, consisting of either a vowel sound (i.e., a nucleus) in the case vocalic endings or a vowel-plus-consonant blend (i.e., a nucleus and a coda) in the case of consonantal endings (Lyster, 2006). I classified noun endings as reliably masculine, reliably feminine, or ambiguous, by considering as reliable predictors of grammatical gender any noun ending that predicted the gender of least $90 \%$ of all nouns in the corpus with that ending. Results revealed that $81 \%$ of all feminine nouns and $80 \%$ of all masculine nouns had endings whose orthographic representations systematically predict their gender. These results provided the impetus for drawing the attention of immersion students-known to have little control of grammatical gender markers even after years of exposure to French (Carroll, 1989; Harley, 1979) — to noun endings as predictors of grammatical gender (see also Harley, 1998).

\subsection{Instructional tasks}

The form-focused tasks were implemented by the regular teachers in six "experimental" classrooms comprising a total of 128 students for approximately 8-10 h over a 5-week period. The tasks and related instructional activities targeted grammatical gender and were embedded in the children's regular curriculum materials, which integrated language arts, social 
studies, and science. A student workbook was created by the research team containing versions of texts found in the regular curriculum materials that had been enhanced to draw students' attention to noun endings as predictors of grammatical gender.

The instructional unit began in the language arts class with a story that students read and discussed called "Le nouveau" about a student's first day at his new school. Students were asked to find the gender of the some of the key words in the story (e.g., attroupement, bouche, casquette, cloche, réaction, récréation, temps, tête) and to already begin inferring rules from the patterns (i.e., nouns ending in / $\widetilde{\mathrm{a}} /$ are masculine, while those ending in $/ \varepsilon t /$, / $/$, and $/ \mathrm{j}$ / / are feminine). The focus then switched to the students' social studies program and their study of the founding of Quebec, Trois-Rivières, and Montreal as colonies in 17th-century New France. The following text illustrates the content about the founding of the settlement at Quebec (where Quebec City stands today), which in turn provided the context into which form-focused tasks were integrated. Note that English translations are provided here for readers of this article but were not made available to students.

Après avoir reçu la mission de fonder une colonie en Nouvelle-France, Samuel de Champlain a choisi, pour faire un établissement permanent, le site où se trouve aujourd'hui la ville de Québec. C'est parce que cet endroit avait un grand avantage: la fourrure y était très présente. [...] De plus, la colonie se situait sur le fleuve St-Laurent, ce qui donnait accès au cour du continent et ouvrait peut-être un passage vers la Chine.

La vie dans la colonie était très dure. Le défrichement de la forêt était difficile et la nourriture manquait. Les colons risquaient donc de mourir de la famine ou encore du scorbut, une maladie très grave. La survie d'une grande partie de la population dépendait donc de la marchandise venant de France. Mais, en 1629, les Anglais ont pris Québec et la Nouvelle-France est restée aux mains de l'Angleterre pendant trois ans. Par la suite, Champlain est revenu pour reprendre les rênes de la colonie.

Petit à petit, la population de la colonie augmentait, le défrichement devenait moins difficile. [...] Aujourd'hui sur la Place-Royale à Québec, on peut toujours visiter Notre-Dame-des-Victoires, une église bâtie en 1688 sur la fondation de l'habitation de Champlain.

After receiving the mission to found a colony in New France, Samuel de Champlain chose to make a permanent establishment, the site where the city of Quebec now stands. This is because this place had a great advantage: the fur there was very present. [...] In addition, the colony was located on the St. Lawrence River, which gave access to the heart of the continent and perhaps opened a passage to China.

Life in the colony was very hard. Clearing the forest was difficult and food was lacking. The settlers therefore could die of starvation or scurvy, a very serious disease. The survival of a large portion of the population depended on merchandise from France. But in 1629, the British took Quebec and New France remained in the hands of England for three years. Thereafter, Champlain returned to take over the colony.

Gradually, the population of the colony increased, and clearing became less difficult. [...] Today on Place-Royale in Quebec, you can still visit Notre-Dame-des-Victoires, a church built in 1688 on the foundation of Champlain's dwelling.

The students' workbook contained a version of the text highlighting target noun endings in bold and requiring students to fill in the missing definite or indefinite article before each noun:

Après avoir reçu __ mission de fonder ___ colonie en Nouvelle-France, Samuel de Champlain a choisi, pour faire établissement permanent, le site où se trouve aujourd'hui la ville de Québec. C'est parce que cet endroit avait grand avantage: ___ fourrure y était très présente. [...] De plus, __ colonie se situait sur le fleuve St-Laurent, ce qui donnait accès au coeur___ continent et ouvrait peut-être__ passage vers Chine.

_ vie dans ___ colonie était très dure. ___ défrichement de la forêt était difficile et___ nourriture manquait. Les colons risquaient donc de mourir de ___ famine ou encore du scorbut, __ maladie très grave. __ survie $d$ ' grande partie de __ population dépendait donc de __ marchandise venant de France. Mais, en 1629, les Anglais ont pris Québec et__ Nouvelle-France est restée aux mains de l'Angleterre pendant trois ans. Par la suite, Champlain est revenu pour reprendre les rênes de __ colonie.

Petit à petit, ___ population de ___ colonie augmentait, ___ défrichement devenait moins difficile. [...] Aujourd'hui sur la Place-Royale à Québec, on peut toujours visiter Notre-Dame-des-Victoires, église bâtie en 1688 sur fondation de l'habitation de Champlain. 
The ensuing awareness activities were inductive rule-discovery tasks requiring students to detect the patterns by classifying the target nouns according to their endings and indicating whether nouns with these endings were masculine or feminine. For example, the students were given the following blank table and were expected to complete it in groups:

\begin{tabular}{lll}
\hline Terminaisons & Noms retrouvés dans le texte & M ou F? \\
\hline
\end{tabular}

The following illustrates a table completed by students based on their analysis:

\begin{tabular}{lll}
\hline Terminaisons & Noms retrouvés dans le texte & $\mathrm{M}$ ou F? \\
\hline -age & un avantage, un passage & $\mathrm{M}$ \\
-tion, -sion & la mission, la population, la fondation & $\mathrm{F}$ \\
-ment, -ent & un établissement, le défrichement, du continent & $\mathrm{M}$ \\
-ine & la Chine, la famine & $\mathrm{F}$ \\
-ie & une/la colonie, la vie, une partie, la survie, une maladie & $\mathrm{F}$ \\
-ise & la marchandise, une église & $\mathrm{F}$ \\
-ure & la fourrure, la nourriture & $\mathrm{F}$ \\
\hline
\end{tabular}

This format was repeated with texts about the founding of Montreal and Trois-Rivières, and again in a True/False exercise about the founding of all three colonies. Students were then given a list of new nouns, which had not appeared in any previous exercises, and were asked to indicate the grammatical gender of each, by adding the right article, based on what they had noticed in previous activities, and then to suggest rules for determining the gender of these nouns. Similar exercises ensued, so there was considerable repetitiveness inherent in these activities although they were always related to the students' subject-matter instruction.

Then for guided oral practice in attributing the right gender marker to target nouns, a set of 100 riddles was used to review the social studies content and to elicit target nouns from students. For example, the riddle (provided in French), "Samuel de Champlain established the first one in New France in 1608," was intended to elicit the noun phrase une colonie but, to stay in the game, students needed to include the right gender-specific determiner. Other riddles to elicit target words related to the content and preceded by correct determiners included the following:

- Cela s'est produit en Nouvelle-France lorsque les colons manquaient de nourriture et crevaient de faim.

LA FAMINE

- (This happened in New France when the settlers lacked food and were starving.)

- Je sers à couvrir certains mammifères. J'ai été très recherchée pendant l'établissement de la Nouvelle-France.

- (I serve to cover certain mammals. I was much sought after during the establishment of New France.)

- Le scorbut, la cause de beaucoup de morts en Nouvelle-France, en est un exemple.

- (Scurvy, the cause of many deaths in New France, is an example.)

- En Nouvelle-France, j'ai augmenté grâce aux naissances et à l'arrivée de nouveaux colons.

- (In New France, I increased due to births and the arrival of new settlers.)

LA FOURRURE

UNE MALADIE

LA POPULATION

To a lesser extent, a similar focus on grammatical gender was integrated into science classes where the topic was "the first machines" (i.e., pulleys, levers, etc.). To review their lesson, students were asked to complete a true/false (vrai ou faux) and to change any false statements into true ones. At the same time, they were also asked to add the right gender-specific determiners to qualify target nouns, as in the following examples:

- __ poulie est ___ machine simple qui n'est plus utilisée aujourd'hui.

- (The pulley is a simple machine that is no longer used today.)

- __ marteau et le pied-de-biche sont des leviers.

- (The hammer and crowbar are levers.

- On peut augmenter la force à l'aide d'___ brouette ou d'___ raquette de tennis.

- (You can increase the force with the use of a wheelbarrow or a tennis racket.)

Upon completion of the task, students were asked to indicate the gender of various words with similar endings (e.g., bureau, carie, cerveau, clarinette, couteau, devinette, recette, sortie, technologie, etc.) and again to formulate rules of thumb for identifying typically masculine nouns (i.e., those ending in [o]) and typically feminine nouns (those ending in -ie and -ette). 


\subsection{Learning outcomes}

The 8-10-h form-focused intervention was implemented by the students' regular teachers over a 5-week period in February and early March. Pretests were administered in January, immediate posttests in March, and delayed posttests in May to students in these six classrooms and to a comparison group comprising 51 students in two other classrooms that did not engage in the form-focused tasks. Instead, they continued with their regular program of study, which included the same curriculum materials used in the treatment classrooms integrating language arts, social studies, and science, but without the researcher-made workbook containing enhanced texts and form-focused tasks designed to draw attention to noun endings as predictors of grammatical gender. The importance of including a comparison group was to ascertain whether mere exposure to subject-matter materials replete with target features would be sufficient to effect any change in these students' ability to correctly assign grammatical gender.

Results of the testing sessions, which took place at three different points in time and included two paper-and-pencil tasks (binary choice and text completion) as well as two oral tasks eliciting spontaneous production (picture description and object identification), showed significant effects for the form-focused tasks. That is, in contrast to the comparison group, the experimental classes demonstrated significant long-term improvement at the time of delayed post-testing on both oral measures and on the binary-choice test, and had also shown significant improvement on the text-completion task at the time of immediate post-testing. The form-focused tasks thus enabled these 5th-grade French immersion students to acquire rulebased representations of grammatical gender and to proceduralize their knowledge of these emerging forms.

\section{Integrating form-focused tasks across language classes}

The second approach to integrating form-focused tasks involved literacy tasks that began in one language (e.g., French) and continued in the other (e.g., English). This approach will be illustrated by a study conducted by Lyster et al. (2013) with three pairs of partner teachers (French/English) participating in a professional development initiative. Their students were in 2nd grade and 7-8 years old. Each pair of partner teachers co-designed and implemented biliteracy tasks focussing on derivational morphology in their respective French and English classes (see Fig. 2). In the spirit of counterbalanced instruction, the language focus was on derivational morphology while the content focus emerged from the themes of illustrated storybooks. Important to note here is that, whereas content-based approaches tend to conceive of content in terms of subject matter such as history, geography, and science, literature can also be seen as a rich source of content in immersion and other content-based settings.

In contrast to L2 teaching approaches that discourage recourse to the students' L1, the applied linguistics literature is increasingly advocating the use of cross-lingual connections to facilitate the role of the L1 as a cognitive resource in L2 learning (e.g., Cook, 2001; Swain \& Lapkin, 2013). Cummins (2007) in particular has argued that, "learning efficiencies can be achieved if teachers explicitly draw students' attention to similarities and differences between their languages and reinforce effective learning strategies in a coordinated way across languages" (p. 233). Cummins argued further that cross-lingual instructional strategies serve to subvert "the two solitudes assumption" (p. 229) that has pervaded immersion programs and kept target languages separate, even though the goal is literacy in two languages (i.e., biliteracy).

To explore the feasibility of cross-lingual pedagogy in the context of French immersion, Lyster, Collins, and Ballinger (2009) implemented a bilingual read-aloud project in three classrooms ranging from 1st to 3rd grade composed of French-dominant, English-dominant, and French/English bilingual students. (See Lyster, 2014, pp. 66-67, for an explanation of the inclusion of French-dominant and French/English bilingual children in French immersion in the Montreal area.). The project aimed to facilitate collaboration between the French and English teachers of the same students as a means of reinforcing the latters' biliteracy skills. The two teachers of each class read aloud to their students from the same storybooks over four months, alternating the reading of one chapter from the French edition and another from the English edition. Prior to each read-aloud session, teachers asked their students to summarize the content of the previous reading, which had taken place in the other

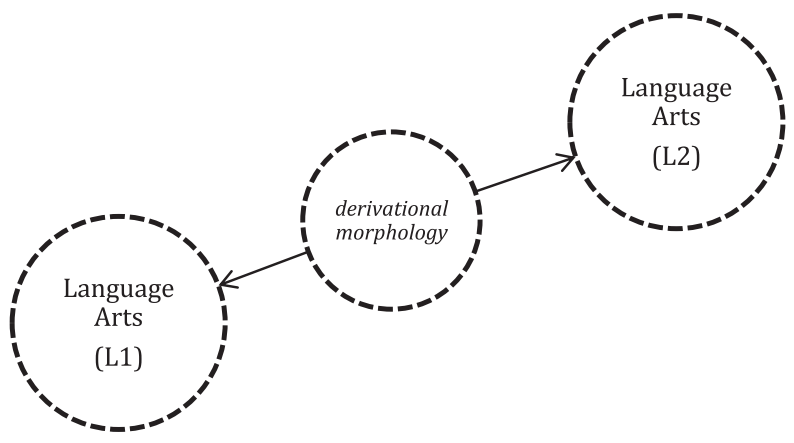

Fig. 2. Integrating form-focused tasks across language classes. 
language of instruction, and after each reading they asked their students to make predictions about the next chapter thereby generating a great deal of student interaction. Students became enthusiastic participants during the reading of the stories in both languages, which appeared to enable the students, irrespective of language dominance, to understand the stories. Many of the students continued to read stories on their own from the same book series, whether in English or French.

While the read-aloud sessions led to some cross-linguistic connections made incidentally, systematic collaboration between partner teachers to make connections across languages was minimal. We concluded that, to exploit the potential of such a project for facilitating teacher collaboration on language-based objectives to the full would require more time for participating teachers to actually collaborate on planning, as well as more structured guidance regarding the language focus.

Based on this conclusion, Lyster et al. (2013) undertook a follow-up study designed to provide (a) more time for participating teachers to actually collaborate on planning and (b) more structured guidance regarding language objectives. Their study was part of a professional development project, which involved a partnership with a local school board and financial support from the Québec Ministère de l'Éducation, du Loisir et du Sport, which enabled participating teachers to be released from their teaching duties so they could take part in a series of professional development workshops.

\subsection{Why focus on derivational morphology?}

Derivational morphology involves adding one or more affixes to a base morpheme to change its meaning or syntactic category. Harley and King (1989) found that, compared to native speakers of French of the same age, L2 learners of French in an immersion program underused derived verbs such as affoler and encercler, while Harley (1992) noted their underuse of productive prefixes such re-for expressing the notion of doing something again (e.g., saying dormir encore instead of the more idiomatic se rendormir to express the idea of going back to sleep). These findings were explained in the light of observational research that revealed considerable emphasis in immersion classrooms on learning the meaning of difficult words but with little attention drawn to the structural properties words and how the productive use of affixes can generate many new words (Allen, Swain, Harley, \& Cummins, 1990). The researchers recommended that teachers could aim to increase students' generative word knowledge through word-focused tasks, explicit vocabulary instruction, and cross-lingual pedagogy.

Even beyond immersion classrooms, Bowers, Kirby, and Deacon (2010) noted that "typical classroom instruction includes very little, if any, systematic and sustained attention to the morphological structure of words" (p. 147). Yet their meta-analysis of 22 studies of morphological instruction from pre-K to 8th grade showed that morphological instruction serves to increase vocabulary size, motivation to investigate words, and reading comprehension. The effects were especially positive when the intervention was combined with other aspects of literacy instruction, as was the case in the Lyster et al. (2013) study, which integrated a focus on derivational morphology with the themes of illustrated storybooks.

\subsection{Instructional tasks}

Teachers in the Lyster et al. (2013) study first drew attention to derived words during the reading aloud of the stories then followed up with tasks or games requiring other words to be formed by analogy with the same affixes. For example, during the reading aloud of Moon Man (Ungerer, 1967/2009; in French: Jean de la Lune), English teachers drew attention to the adjective mysterious, which appeared as a key word to describe the protagonist, by helping students to identify the noun mystery as its base and then to form by analogy either similar adjectives (e.g., courageous from courage) or nouns (e.g., disaster from disastrous). In the French version, the word courageux occurred as a key attribute in the narrative and so French teachers helped students to identify the noun courage as its base and to generate by analogy either similar adjectives (e.g., paresseux from paresse) or nouns (e.g., mystère from mystérieux).

For the sake of coherence across the curriculum, this project emphasized biliteracy tasks that began in one language and continued in the other. For example, the teacher of one language read aloud The Three Robbers (Ungerer, 1962/2008; in French: Les trois brigands), but stopped when she reached an important point in the story, when the protagonist discovers the robbers' hidden treasures and asks them how they would spend all their money. The teacher then asked students to make oral predictions about how they thought the money might be spent and to illustrate their predictions along with written annotations. In the next class, in the other language, the teacher asked students to retell their predictions and then proceeded to read the rest of the story. At the end, students were asked to compare their predictions with the actual ending, in which the robbers "set off and gathered up all the lost, unhappy, and abandoned children they could find" and "bought a beautiful castle where all of them could live."

The students' attention was then drawn to derivational morphology - by the English teacher who pointed out the use and meaning of the prefix un- in unhappy and by the French teacher who pointed out the use and meaning of the prefix mal-in malheureux. The teachers followed up in their respective classes with tasks or games requiring other words to be formed by analogy with the same prefixes. In English, this included adjectives such as unable and unbelievable and verbs such as unfold and unpack. In one class, the teacher covertly asked individual students to mime words such as unfold or unpack for the others to guess what action was being mimed. In French, teachers drew attention to adjectives such as malhonnête and malpoli but, because mal-is limited in its use as an adjectival prefix, they extended their focus to include the much more productive prefix in- in words such as incapable and incroyable.

Another biliteracy task that began in one language and continued in the other stemmed from the reading aloud of Crictor (Ungerer, 1958). The eponymous character in this story is a boa constrictor given as a gift to Mme Bodot, a schoolteacher living 
in Paris. She goes out of her way to make Crictor feel comfortable in her home, installing a long bed for him alongside palm trees and even knitting him a long scarf. In turn, Crictor makes himself useful at her school, helping the children at school learn to count, read the alphabet and tie knots, and serving as a slide and a skipping rope. At the story's climax, Crictor saves Mme Bodot from a burglar who has gagged her and tied her up, so becomes a hero, is awarded a medal for his bravery, and a statue is erected in his honour.

The derivational relationships in reference to Crictor's heroic traits were emphasized by the words hero and heroism in the English class and héros and héroisme in the French class. English teachers drew attention to the suffix -ic in heroic to encourage students to discover similar derivations (e.g., science $\Rightarrow$ scientific; history $\Rightarrow$ historic), while French teachers drew attention to the suffix -ique in héroïque to encourage students to discover analogous derivations in French (e.g., science $\Rightarrow$ scientifique; histoire $\Rightarrow$ historique). Still other word-focused tasks deemed appropriate and relevant by the teachers dwelt on similar patterns of suffixation in words whose meanings were closely tied to the story (e.g., courage $\Rightarrow$ courageous or courageux; danger $\Rightarrow$ dangerous or dangereux).

One pair of teachers co-designed and implemented a biliteracy task related to Crictor and based on the theme of adaptation, which they considered to underpin the narrative: That is, while Mme Bodot helped Crictor to adapt to his new home, Crictor was adapting to his new community by being so helpful. So the teachers presented students with information about four other animals (giraffes, octopuses, porcupines, and bats) to interest them in imagining having one as a pet. After orally brainstorming various scenarios, students in the English class each created an annotated illustration depicting what they would do to help their pet adapt to its new home, while in the French class they made an annotated illustration of how the same pet would adapt to its new community by being helpful. The final product was a bilingual class book portraying each student's contribution in French and English on facing pages.

\subsection{Learning outcomes}

To measure the effects of the form-focused biliteracy tasks on student outcomes, a French version and an English version of a Morphological Awareness Test (Quiroga, 2013) was administered as a pretest and posttest to a subsample of 45 students exposed to the biliteracy instruction (i.e., the experimental group) and to a comparison group of 20 students from two schools in the same school board whose teachers had not participated in the project.

The between-group comparisons showed that, at the time of post-testing, the group receiving the instructional treatment significantly outperformed the comparison group in French, but not in English, and these positive effects in French were similar for all students receiving the instruction irrespective of language dominance. In English, although students receiving the instruction did not, as a group, outperform students not receiving the instruction, the English-dominant students receiving the instruction significantly outperformed their counterparts not receiving the instruction on the English measure. In addition, participating teachers' perceptions were positive and enthusiastic. They appreciated the time to collaborate and were impressed by their students' positive reactions to the biliteracy instruction, observing that students "enjoyed making connections between the two languages" (Lyster et al., 2013, p. 187).

\section{Confronting challenges and looking ahead}

In the case of both studies reviewed here, learners made significant progress in their language development after engaging in form-focused tasks that were integrated either across content areas through their L2 or across their language arts classes in both L1 and L2. The tasks employed to integrate a language focus across content areas in the first study had been designed by a team of researchers and were implemented by individual teachers who taught all the content areas in question. Challenges in this regard would be, first, for teachers to design such language-and-content integrated tasks on their own without the support of specialists in this area and, second, to collaborate with colleagues to integrate a specific language focus in contexts where the different content areas are taught by different teachers.

To some extent, the second study addressed these challenges, first by engaging teachers in the development of the instructional tasks and, second, by facilitating collaboration between teachers-not necessarily of different content areas, however, but rather of different languages. The strength of this project lay in the teacher collaboration, and its collaborative design could serve as a model for teachers to foster integrated learning not only across languages but also across content areas. The study also contributed to the instructed L2 acquisition literature by adding a professional development component to research on form-focused instruction for the purpose of strengthening educational practice. Finally, this project and its forerunner (Lyster et al., 2009) together succeeded in bringing children's literature to the fore as a rich and engaging source of both language and content in biliteracy tasks designed to begin in one language and continue in another.

A challenge for teachers across both studies is the linguistic knowledge required to design form-focused tasks that are well integrated across content areas or across languages. The linguistic foci of both studies reviewed here are a case in point. For instance, drawing learners' attention to noun endings as clues to grammatical gender begs the simple question as to what exactly a noun ending is: Is it the final grapheme, the final phoneme, the final syllable, or a rhyme? Indicative of the complexity of determining what constitutes a noun ending, Carroll (1989) made the bold claim that "Endings do not exist" (p. 563). In my study, based on a detailed corpus analysis of nearly 10,000 nouns (Lyster, 2006), noun endings were carefully operationalized as orthographic representations of rhymes consisting of either a nucleus in the case of vocalic endings or a nucleus and a coda in the case of consonantal endings. However, this definition remained rather abstract for teachers. 
Similarly, drawing students' attention to derivational morphology brings to the fore the confounding fact that what appears to be an affix may no longer function as one (or never did). For example, whereas 'redo' is composed of two morphemes that together mean 'to do again', the word 'repeat' now functions as a single morpheme that does not mean 'to peat again' (although its etymology can be traced to two separate morphemes). Because some advanced linguistic knowledge is necessary to integrate form-focused tasks in content areas and literacy activities, this is a domain where applied researchers can provide useful support to teachers during collaborative projects such as the school-based initiatives described in this article.

Looking ahead to possibilities for language across the immersion curriculum, one could envision an ideal model of integration that incorporated instructional approaches represented by both Figs. 1 and 2 so that teacher collaboration would promote integrated learning across target languages while also making coherent connections across content areas. Tasks would be pivotal in such a cross-curricular approach and would be designed to provide purposeful opportunities for strengthening connections between language and content learning. Defining task broadly as "any activity that learners engage in to further the process of learning a language" (p. 168), Williams and Burden (1997) suggested that tasks for schoolage learners can be made purposeful by investing them with an educational rationale, such as the development of thinking skills, problem-solving skills, and learning how to learn. Because academic tasks undertaken in immersion typically aim to engage students with subject matter, they are invested ipso facto with educational purpose and also have much potential for engaging students with language across the immersion curriculum.

\section{Acknowledgements}

The study by Lyster (2004) received financial support from the Social Sciences and Humanities Research Council of Canada (\#410-98-0175 and \#410-2002-0988), while the study by Lyster et al. (2013) was supported by a grant from the Québec Ministère de l'Éducation, du Loisir et du Sport. An earlier version of this paper was presented as part of the invited colloquium called "The interface between TBLT and content-based instruction" organized by María del Pilar García Mayo at the International Conference on Task-Based Language Teaching held in Banff (Alberta) in October 2013.

\section{References}

Allen, P., Swain, M., Harley, B., \& Cummins, J. (1990). Aspects of classroom treatment: toward a more comprehensive view of second language education. In B. Harley, P. Allen, J. Cummins, \& M. Swain (Eds.), The development of second language proficiency (pp. 57-81). Cambridge, UK: Cambridge University Press.

Bowers, P., Kirby, J., \& Deacon, H. (2010). The effects of morphological instruction on literacy skills: a systematic review of the literature. Review of Educational Research, 80, 144-179.

Brown, L. (Ed.). (1993). The new shorter Oxford English dictionary. Oxford: Clevedon Press.

Bullock, A. (1975). A language for life. London: Department of Education and Science.

Cammarata, L., \& Tedick, D. J. (2012). Balancing content and language in instruction: the experience of immersion teachers. The Modern Language Journal, 96, 251-269.

Carroll, S. (1989). Second-language acquisition and the computational paradigm. Language Learning, 39, 535-594.

Cook, V. (2001). Using the first language in the classroom. The Canadian Modern Language Review, 57, $402-423$.

Cummins, J. (2007). Rethinking monolingual instructional strategies in multilingual classrooms. Canadian Journal of Applied Linguistics, $10,221-241$.

Day, E., \& Shapson, S. (2001). Integrating formal and functional approaches to language teaching in French immersion. Language Learning, 51(Suppl. 1), 47-80.

Doughty, C., \& Williams, J. (1998). Pedagogical choices in focus on form. In C. Doughty, \& J. Williams (Eds.), Focus on form in classroom second language acquisition (pp. 197-261). Cambridge, UK: Cambridge University Press.

Harley, B. (1979). French gender 'rules' in the speech of English-dominant, French-dominant, and monolingual French-speaking children. Working Papers in Bilingualism, 19, 129-156.

Harley, B. (1989). Functional grammar in French immersion: a classroom experiment. Applied Linguistics, 10, 331-359.

Harley, B. (1992). Patterns of second language development in French immersion. Journal of French Language Studies, 2, $159-183$.

Harley, B. (1998). The role of form-focused tasks in promoting child L2 acquisition. In C. Doughty, \& J. Williams (Eds.), Focus on form in classroom second language acquisition (pp. 156-174). Cambridge, UK: Cambridge University Press.

Harley, B., \& King, M. (1989). Verb lexis in the written compositions of young L2 learners. Studies in Second Language Acquisition, 11, 415-439.

Karmiloff-Smith, A. (1979). A functional approach to child language. Cambridge, UK: Cambridge University Press.

Krashen, S. (1984). Immersion: why it works and what it has taught us. Language and Society, 12, 61-68.

Krashen, S. (1985). The input hypothesis: Issues and implications. London: Longman.

Lightbown, P. M. (2014). Focus on content-based language teaching. Oxford: Oxford University Press.

Lightbown, P. M., \& Spada, N. (1990). Focus on form and corrective feedback in communicative language teaching: effects on second language learning. Studies in Second Language Acquisition, 12, 429-448.

Long, M. (1991). Focus on form: a design feature in language teaching methodology. In K. de Bot, R. Ginsberg, \& C. Kramsch (Eds.), Foreign language research in cross-cultural perspective (pp. 39-52). Amsterdam: John Benjamins.

Lyster, R. (1994). The effect of functional-analytic teaching on aspects of French immersion students' sociolinguistic competence. Applied Linguistics, 15, 263-287.

Lyster, R. (2004). Differential effects of prompts and recasts in form-focused instruction. Studies in Second Language Acquisition, 26, 399-432.

Lyster, R. (2006). Predictability in French gender attribution: a corpus analysis. Journal of French Language Studies, 16, 69-92.

Lyster, R. (2007). Learning and teaching languages through content: A counterbalanced approach. Amsterdam: John Benjamins.

Lyster, R. (2014). Children's literature as a catalyst for dual language awareness. In C. Hélot, R. Sneddon, \& N. Daly (Eds.), Children's literature in the multilingual classroom (pp. 64-83). London: Trentham Books/Institute of Education Press.

Lyster, R., Collins, L., \& Ballinger, S. (2009). Linking languages through a bilingual read-aloud project. Language Awareness, $18,366-383$.

Lyster, R., \& Mori, H. (2006). Interactional feedback and instructional counterbalance. Studies in Second Language Acquisition, 28, 269-300.

Lyster, R., Quiroga, J., \& Ballinger, S. (2013). The effects of biliteracy instruction on morphological awareness. Journal of Immersion and Content-Based Language Education, 1(2), 169-197. 
Poirier, J., \& Lyster, R. (2014). Les pronoms objets directs de la $3^{\mathrm{e}}$ personne et leur apport aux indices du genre grammatical dans le discours oral des enseignants en immersion. La Revue canadienne des langues vivantes, 70(2), 246-267.

Quiroga, J. (2013). Measuring morphological awareness across languages (Unpublished master's thesis). Montreal, Canada: McGill University.

Rebuffot, J., \& Lyster, R. (1996). L'immersion au Canada: contextes, effets et pédagogie. In J. Erfurt (Ed.), De la polyphonie à la symphonie. Méthodes, théories et faits de la recherche pluridisciplinaire sur le français au Canada (pp. 277-294). Leipzig: Leipziger Universitätsverlag GmbH.

Skehan, P. (1998). A cognitive approach to language learning. Oxford: Oxford University Press.

Spada, N. (1997). Form-focussed instruction and second language acquisition: a review of classroom and laboratory research. Language Teaching, $29,73-87$. Stern, H. H. (1990). Analysis and experience as variables in second language pedagogy. In B. Harley, P. Allen, J. Cummins, \& M. Swain (Eds.), The development of second language proficiency (pp. 93-109). Cambridge, UK: Cambridge University Press.

Swain, M. (1985). Communicative competence: some roles of comprehensible input and comprehensible output in its development. In S. Gass, \& C. Madden (Eds.), Input in second language acquisition (pp. 235-253). Rowley, MA: Newbury House.

Swain, M., \& Lapkin, S. (2013). A Vygotskian sociocultural perspective on immersion education: the L1/L2 debate. Journal of Immersion and Content-Based Education, 1, 101-129.

Tucker, R., Lambert, W. E., \& Rigault, A. (1977). The French speaker's skill with grammatical gender: An example of rule-governed behaviour. Paris: Mouton.

Ungerer, T. (1958). Crictor. New York: Harper Collins.

Ungerer, T. (1962/2008). The three robbers. New York: Phaidon.

Ungerer, T. (1967/2009). Moon man. New York: Phaidon.

Williams, M., \& Burden, R. (1997). Psychology for language teachers: A social constructivist approach. Cambridge, UK: Cambridge University Press.

Wright, R. (1996). A study of the acquisition of verbs of motion by grade 4/5 early French immersion students. The Canadian Modern Language Review, 53, $257-280$. 